\title{
Preliminary Characterization of Three Metallurgical Bauxite Residue Samples ${ }^{\dagger}$
}

\author{
Panagiotis Angelopoulos ${ }^{1}{ }^{\complement}$, Maria Georgiou ${ }^{1, *}$, Paschalis Oustadakis ${ }^{1} @$, Maria Taxiarchou ${ }^{1}$, Hakan Karadağ ${ }^{2}$, \\ Yasin Eker ${ }^{2}{ }^{1}$, Gheorghe Dobra ${ }^{3}$, Alina Boiangiu ${ }^{3}$, Gökhan Demir ${ }^{4}$, Sedat Arslan ${ }^{4}$, Panagiotis Davris ${ }^{5}$ \\ and Efthymios Balomenos 5
}

1 School of Mining \& Metallurgical Engineering, National Technical University of Athens (NTUA), 15780 Athens, Greece; pangelopoulos@metal.ntua.gr (P.A.); oustadak@metal.ntua.gr (P.O.); taxiarh@metal.ntua.gr (M.T.)

2 Department of Metallurgical and Materials Engineering, Necmettin Erbakan Üniversitesi (NEU), 42090 Konya, Turkey; hbkaradag@erbakan.edu.tr (H.K.); yeker@erbakan.edu.tr (Y.E.)

3 Alum Tulcea, 820228 Tulcea, Romania; dobra@alro.ro (G.D.); aboiangiu@alum.ro (A.B.)

4 ETI Aluminyum A.S., 42370 Konya, Turkey; gokhan.demir@etialuminyum.com (G.D.); sedat.arslan@etialuminyum.com (S.A.)

5 MYTILINEOS SA, 32003 Viotia, Greece; panagiotis.davris@alhellas.gr (P.D.); thymis@metal.ntua.gr (E.B.)

* Correspondence: mgeorgiou@metal.ntua.gr; Tel.: +30-21-0772-4482

+ Presented at International Conference on Raw Materials and Circular Economy, Athens, Greece, 5-9 September 2021.

Citation: Angelopoulos, P.; Georgiou, M.; Oustadakis, P.; Taxiarchou, M.; Karadağ, H.; Eker, Y.; Dobra, G.; Boiangiu, A.; Demir, G.; Arslan, S.; et al. Preliminary Characterization of Three

Metallurgical Bauxite Residue Samples. Mater. Proc. 2021, 5, 66. https://doi.org/10.3390/ materproc2021005066

Academic Editor: Evangelos Tzamos

Published: 8 December 2021

Publisher's Note: MDPI stays neutral with regard to jurisdictional claims in published maps and institutional affiliations.

Copyright: (c) 2021 by the authors. Licensee MDPI, Basel, Switzerland. This article is an open access article distributed under the terms and conditions of the Creative Commons Attribution (CC BY) license (https:/ / creativecommons.org/licenses/by/ $4.0 /)$.
Abstract: Bauxite Metallurgical Residue (BR) is a highly alkaline and very fine-grained by-product of the Bayer process for alumina production. Its huge global annual production has resulted in increasing accumulation of BR, causing deposition problems and serious environmental issues. RM contains oxides and salts of the main elements $\mathrm{Fe}, \mathrm{Al}, \mathrm{Ca}, \mathrm{Na}, \mathrm{Si}, \mathrm{Ti}$, and rare earths- $\mathrm{REEs}(\mathrm{Sc}$, $\mathrm{Nd}, \mathrm{Y}, \mathrm{La}, \mathrm{Ce}, \mathrm{Ds}$ ) - many of which have been categorised by EU as critical metals (CMs). The valorisation of BR as a low-cost secondary raw material and metal resource could be a route for its reduction, introducing the waste into the economic cycle. REEScue constitutes a research project that aims to instigate the efficient exploitation of European bauxite residues, resulting from alumina production from Greece (MYTILINEOS SA), Turkey (ETI Aluminium), and Romania (ALUM SA), containing appreciable concentrations of scandium and REEs, through the development of a number of innovative extraction and separation technologies that can efficiently address the drawbacks of the existing solution. The consortium consists of three alumina producers from Greece (MYTILINEOS SA), Turkey (ETI Aluminium), and Romania (ALUM SA) and two academic partners from Greece (National Technical University of Athens) and Turkey (Necmettin Erbacan University). We present preliminary characterization results of three different BR samples that originate from the three aluminium industries, in respect of bulk chemical analysis (XRF, ICP), mineralogical investigation (XRD), and morphological observation through microscopy.

Keywords: bauxite residue; Bayer process; rare-earth elements (REE); waste valorisation; scandium

\section{Introduction}

Bauxite residue (BR) is a highly alkaline and very fine-grained by-product of the Bayer process for alumina production. Its huge global annual production, 150 million tonnes [1], has resulted in increasing accumulation of BR, causing deposition problems and serious environmental impacts. It is relatively toxic, not only due to its high alkalinity ( $\mathrm{pH} 10-12.5)$, but also because of the presence of numerous heavy and radioactive metals $(\mathrm{V}, \mathrm{Cr}, \mathrm{Cd}, \mathrm{Ni}$, $\mathrm{Zn}, \mathrm{Pb}, \mathrm{Ba}, \mathrm{Sr}, \mathrm{Hf}, \mathrm{Nd}, \mathrm{U}$, and Th) in small quantities [2].

The exact chemical composition of the BR depends upon the mineralogical composition of the bauxite ore and the specific processing conditions through the Bayer process. 
A typical BR material contains, indicatively, on average: $17 \% \mathrm{Al}_{2} \mathrm{O}_{3}, 41 \% \mathrm{Fe}_{2} \mathrm{O}_{3}, 9 \% \mathrm{TiO}_{2}$, $10 \% \mathrm{SiO}_{2}, 9 \% \mathrm{CaO}$, and $5 \% \mathrm{Na}_{2} \mathrm{O}$ [3]. Red mud residues contain notable concentrations of rare-earth elements up to $2500 \mathrm{ppm}$ have been reported; however, a typical $\Sigma$ REE is around $1000 \mathrm{ppm}$ [4]. Sc concentrations detected in bauxite residues worldwide range from 41 to $254 \mathrm{mg} / \mathrm{kg}$, while typical concentrations are in the range of 50-100 ppm [5]. This concentration is five times higher than the average Sc concentration in the Earth's crust and very close to the Sc concentration in main scandium resources. Therefore, $\mathrm{BR}$ is a valuable secondary resource, rich in base metals, rare-earth elements, and scandium [3]. Therefore, the utilisation of BR is of great economic and environmental importance.

$\mathrm{BR}$ is generally disposed of in the environment, causing environmental problems, such as surface water and groundwater pollution [6]. In Europe, alumina and primaryaluminium industries utilise about 12 million tonnes of bauxite to produce about 7 million tons of alumina. Alumina refineries operate in Bosnia, Herzegovina, France, Hungary, Germany, Greece, Ireland, Romania, Spain, and Ukraine; while significant BR deposits from refineries that have stopped their operations (legacy sites) exist in Italy, France, Germany, Hungary, and other countries. The current BR production in the EU is 6.8 million tonnes per year and it is estimated that the cumulative BR stockpile is more than 250 million tonnes.

Three alumina refineries participate in REEScue project (https: / / reescue.com): Aluminum of Greece (AoG) (Greece), ETI Seydisehir Aluminyum S.A. (ETI) (Turkey), and VIMETCO (Alum) (Romania), producing annually about 750,000, 440,000, and 450,000 tons of BR, respectively. In total, these three plants produce about 1,640,000 tons of BR, annually, on top of the already stockpiled BR in tailing ponds or filtercake landfills, which is over $15 \mathrm{Mt}$. As land availability is becoming limited, together with increasingly stringent environmental protection regulations, the management of the large volume of BR produced during the Bayer process has become of great concern to alumina producers. The evergrowing demand of space for BR disposal threatens the longevity of the operating alumina refineries. The main aim of the REEScue project is the efficient exploitation of European bauxite residues resulting from alumina production, containing appreciable concentrations of scandium ( up to $1000 \mathrm{ppm}$ ) and REEs ( $1000 \mathrm{ppm}$ TREE) [4,5], through the development of a number of innovative extraction and separation technologies that can efficiently address the drawbacks of the existing solutions. The project concept and the proposed technical solutions are based on the smart combination of physical and hydrometallurgical processes that will enable the following: (i) the production of a marketable magnetite concentrate corresponding to about $35 \%$ of the processed BR quantity; (ii) the efficient processing of the remaining residue to achieve maximum extraction and recovery of Sc and REEs; and (iii) the production of a commercial alumina-rich material, suitable for its use as a raw material in the cement industry or for the production of geopolymers.

Here, we present the preliminary characterization results for all the bauxite residue grades considered in the project. Properties that are considered are chemical analyses, including major REE elements and quantitative mineralogical analysis. Microscale observation of the samples was performed in combination SEM-EDS. The differences identified among samples' properties are attributed to the raw material characteristics, as well as the processing conditions for the extraction of alumina.

\section{Materials and Methods}

Major element chemical composition was measured through X-ray fluorescence (Xepos Spectro Bench Instrument, Spectro, Kleve, Nordrhein-Westfalen, Germany). The rare-earth elements and scandium contents of each bauxite residue were measured using ICP-OES instrument. Bulk solid phase characterization was performed through X-ray diffraction using a Bruker D8 Focus diffractometer with $\mathrm{Cu}-\mathrm{K} \alpha$ (Ni filtered) radiation in the 2-theta range, from $5^{\circ}$ to $75^{\circ}$ and $0.02^{\circ}$.sec- 1 step. The Rietveld analysis option of the software has been applied to the diffractogram between $5^{\circ}$ and $90^{\circ}$, using PROFEX freeware [7]. The morphology and chemical composition of the samples in microscale was examined by scanning electron microscopy using a Jeol 6380LV microscope under 15 and $20 \mathrm{kV}$ 
accelerating voltage. Local chemical composition of the samples was analysed on an Oxford INCA energy dispersive spectrometer (EDS), connected to the SEM.

\section{Results and Discussion}

\subsection{Chemical Composition}

The chemical analyses results are presented in Tables 1 and 2. Samples present high content in iron oxide, which in all cases exceeds $30 \%$. Residual aluminium is also present in amount that ranges between $12 \%$ and $16 \%$. The Greek sample (BR AoG) and the Romanian sample (BR ALUM) present significantly low sodium contents compared with the other sample. A number of major rare-earth elements were measured via ICP-OES and their concentrations are presented in Table 2. At this point, it should be stressed that the ICPOES technique initially detects the presence of REEs and scandium in all three of the BR samples, however provided partial semiquantitative chemical composition. The Greek and Turkish samples presented a high cerium content, which presents minor economic interest (due to its relatively low trade value), and marginally higher than $130 \mathrm{mg} / \mathrm{kg}$ of lanthanum. Scandium was also identified in all three samples, ranging between $76 \mathrm{mg} / \mathrm{kg}$ and $150 \mathrm{mg} / \mathrm{kg}$.

Table 1. Chemical composition of bauxite residue samples (XRF).

\begin{tabular}{cccc}
\hline Oxide & BR ALUM (\%) & BR AoG (\%) & BR ETI (\%) \\
\hline $\mathrm{Na}_{2} \mathrm{O}$ & 5.94 & 3.94 & 15.63 \\
$\mathrm{MgO}$ & 0.58 & 0.18 & 0.26 \\
$\mathrm{Al}_{2} \mathrm{O}_{3}$ & 15.85 & 15.40 & 15.33 \\
$\mathrm{SiO}_{2}$ & 9.92 & 8.27 & 14.06 \\
$\mathrm{~K}_{2} \mathrm{O}$ & 0.078 & 0.13 & 0.47 \\
$\mathrm{CaO}$ & 5.27 & 9.46 & 6.99 \\
$\mathrm{TiO}_{2}$ & 2.81 & 6.16 & 5.29 \\
$\mathrm{Cr}_{2} \mathrm{O}_{3}$ & 0.14 & 0.29 & 0.07 \\
$\mathrm{Fe}_{2} \mathrm{O}$ & 46.70 & 32.36 \\
$\mathrm{NiO}$ & 45.97 & 0.12 & 0.05 \\
$\mathrm{LOI}$ & 0.012 & 8.29 & 8.29 \\
$\mathrm{Other}$ & 11.97 & 1.06 & 1.20 \\
\hline
\end{tabular}

Table 2. Partial chemical composition of Bauxite residue samples (ICO OES).

\begin{tabular}{cccc}
\hline Element & BR ALUM (mg/kg) & BR AoG $\mathbf{( m g} / \mathbf{k g})$ & BR ETI $(\mathbf{m g} / \mathbf{k g})$ \\
\hline La & $<100$ & 133.3 & 142 \\
Ce & $<100$ & 304.1 & 392 \\
Y & $<200$ & $<200$ & 135 \\
Nd & $<200$ & $<200$ & 178 \\
Sc & $\sim 150$ & $\sim 150$ & 76 \\
\hline
\end{tabular}

\subsection{Bulk Solid Phase Characterization}

Figures 1 and 2 present the XRD diagrams of bulk BR samples, while Table 3 presents their mineralogical compositions, calculated according to Rietveld methodology. 


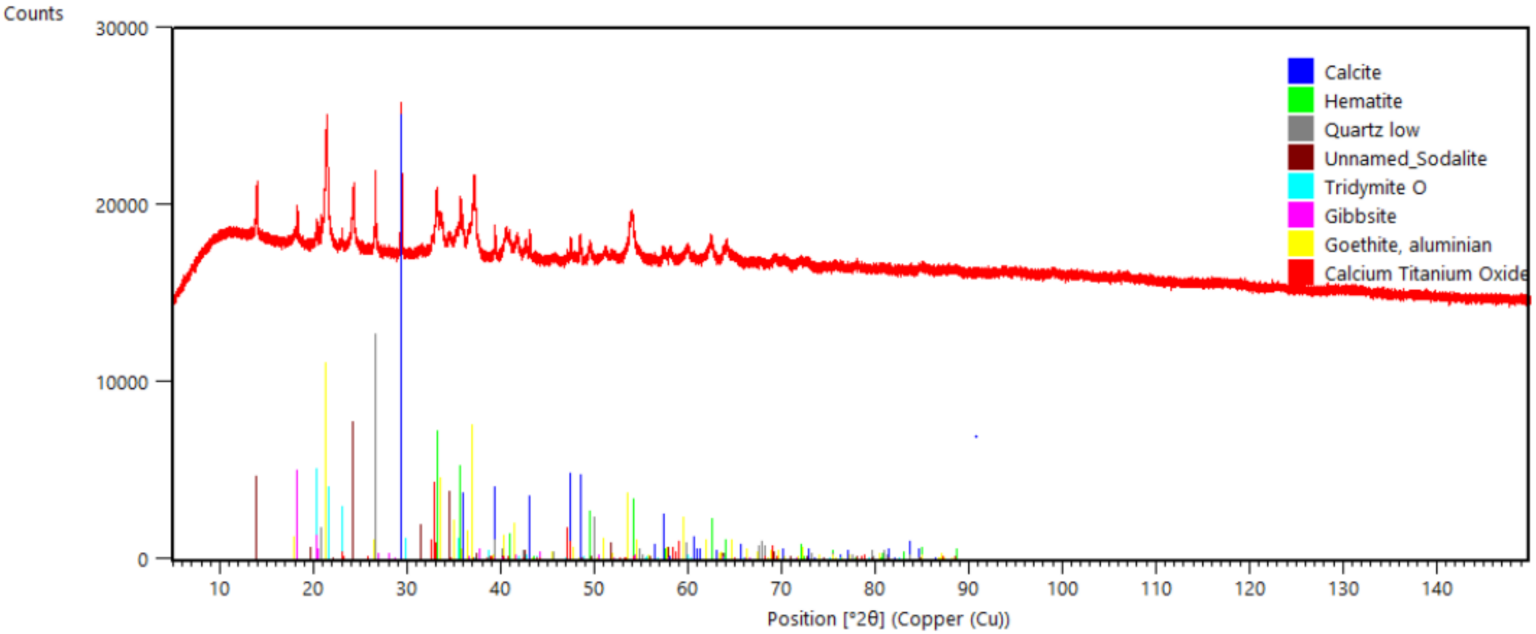

(a)

Counts

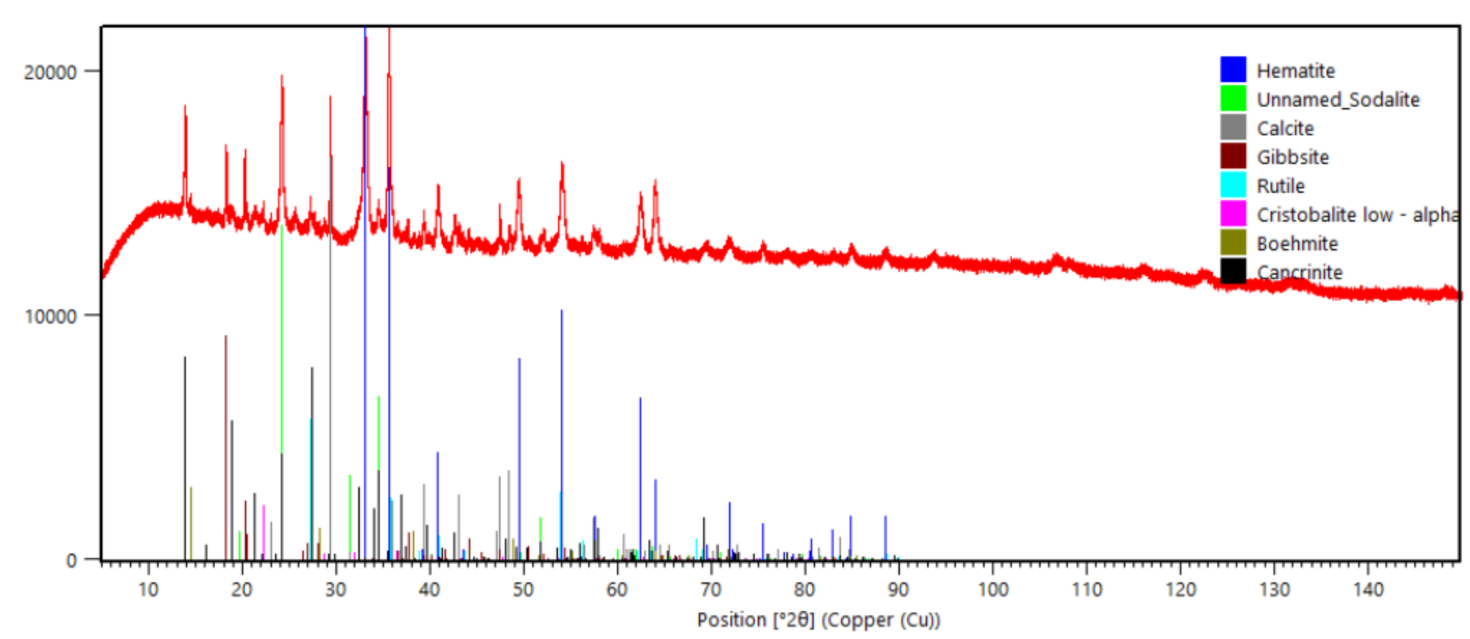

(b)

Figure 1. (a) Phases of BR from ALUM. (b) Phases of BR from ETI.

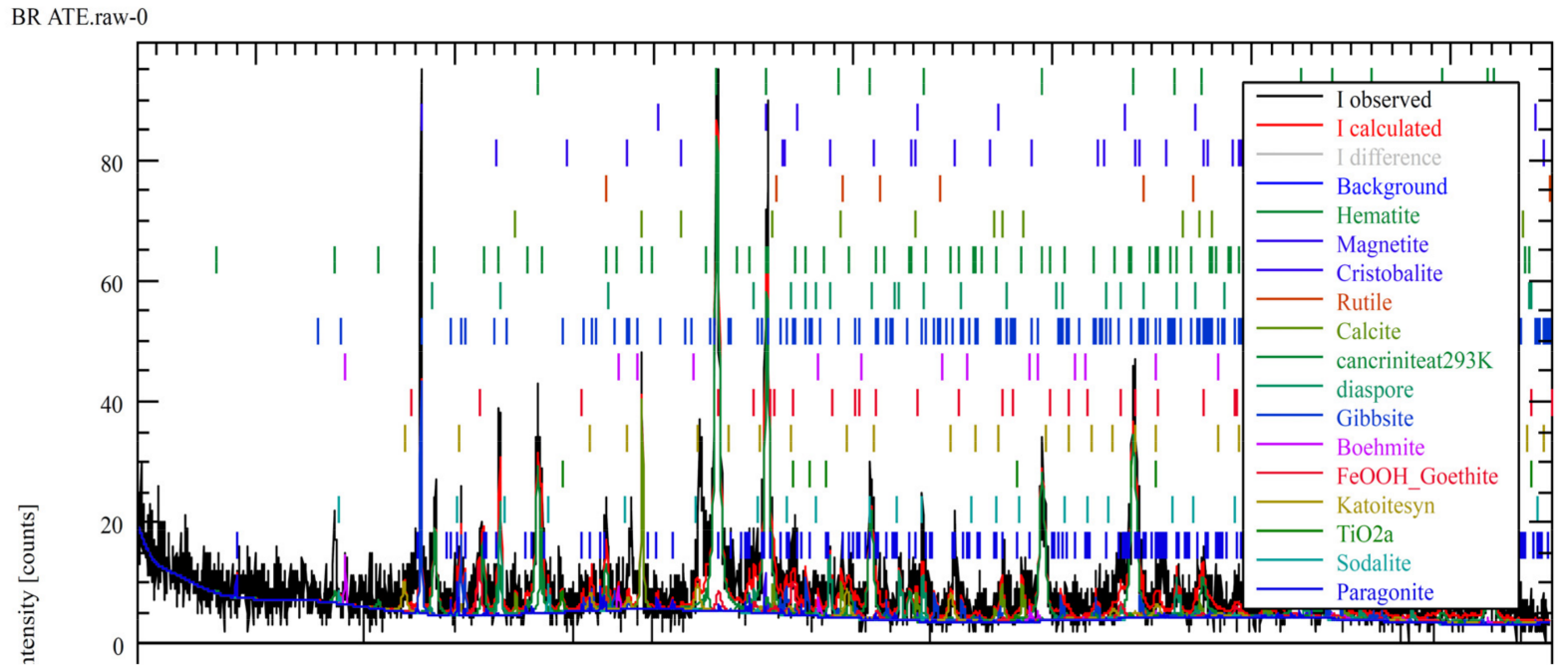

Figure 2. Phases of BR from AoG. 
Table 3. Structures on BR of ALUM, AoG, and ETI and their distribution according to Rietveld analysis method.

\begin{tabular}{|c|c|c|c|c|}
\hline \multirow{2}{*}{ Compound Name } & \multirow{2}{*}{ Chemical Formula } & \multicolumn{3}{|c|}{ Content (\%) } \\
\hline & & BR-ALUM & BR-AoG & BR-ETI \\
\hline Goethite, aluminian & $\mathrm{Al}_{0.1} \mathrm{Fe}_{0.9} \mathrm{OH}$ & 46.3 & 15.63 & \\
\hline Sodalite & $\mathrm{Al}_{6} \mathrm{Na}_{6} \mathrm{Si}_{6} \mathrm{C}_{2.4} \mathrm{O}_{34.32} \mathrm{H}_{23.04}$ & 18.4 & 0.7 & 20.9 \\
\hline Hematite & $\mathrm{Fe}_{2} \mathrm{O}_{3}$ & 13.9 & 43.0 & 44.7 \\
\hline Magnetite & $\mathrm{Fe}_{3} \mathrm{O}_{4}$ & & 0.5 & \\
\hline Cancrinite & $\mathrm{Al}_{6} \mathrm{Na}_{7.14} \mathrm{Si}_{7.08} \mathrm{O}_{31.6} \mathrm{H}_{9.74}$ & & 18.0 & 12.9 \\
\hline Calcite & $\mathrm{CaCO}_{3}$ & 11.8 & 6.7 & 7.9 \\
\hline Quartz low & $\mathrm{SiO}_{2}$ & 3.4 & & \\
\hline Gibbsite & $\mathrm{Al}(\mathrm{OH})_{3}$ & 3.2 & 9.0 & 6.7 \\
\hline Paragonite & $\mathrm{Al}_{3} \mathrm{NaSi}_{3} \mathrm{O}_{12} \mathrm{H}_{2}$ & & 3.0 & 3.5 \\
\hline Boehmite & $\mathrm{AlO}(\mathrm{OH})$ & & 1.3 & 1.0 \\
\hline Diaspore & $\alpha-\mathrm{AlO}(\mathrm{OH})$ & & 9.0 & \\
\hline $\begin{array}{l}\text { Calcium Sodium Aluminium } \\
\text { Oxide }(8.3 / 1.5 / 6 / 18)\end{array}$ & $\mathrm{Al}_{6} \mathrm{Ca}_{8.25} \mathrm{Na}_{1.5} \mathrm{O}_{18}$ & & & 0.9 \\
\hline Tridymite $\mathrm{O}$ & $\mathrm{SiO}_{2}$ & 2.9 & & \\
\hline Cristobalite- $\alpha$ & $\mathrm{SiO}_{2}$ & & & 0.8 \\
\hline Calcium Titanium Oxide & $\mathrm{CaTiO}_{3}$ & 0.3 & & \\
\hline Rutile & $\mathrm{TiO}_{2}$ & & 0.4 & 0.6 \\
\hline
\end{tabular}

Regarding ALUM BR, it mainly contains goethite, sodalite, hematite, and calcite in contents of about $46.3 \%, 18.4 \%, 13.9 \%$, and $11.8 \%$, respectively. AoG BR contains mainly iron oxides, rutile, calcite, and allotropic forms of silica and secondary phases produced through the Bayer process such as cancrinite. Iron is found in the form of hematite, in contents of about $43 \%$. Minor quantity of magnetite is also identified but its content is well below $1 \%$. Significant amounts of aluminium minerals, such as gibbsite and diaspore, were present in the sample, in a total amount of almost $18 \%$. Sample ETI mainly contains hematite of about $44.7 \%$ and sodalite at $20.9 \%$. Cancrinite was also identified in an amount of $12.9 \%$.

\subsection{Morphology}

The current section presents the results of morphological observation of samples (Figure 3) with local chemical analysis defined by SEM-EDS. Regarding ALUM BR, the EDS mapping of the major elements clearly shows that the residue mainly contains iron (Figure 4). Colour intensities on mapping indicate that some particles only consist in pure metal oxides or hydroxides, while others contain two or more metallic elements (Na-Si, $\mathrm{Fe}-\mathrm{Si}$ ). The semi-quantitative analysis given with the EDS spectrum confirm the order of the major metal present within ALUM BR $(\mathrm{Fe}>\mathrm{Al}>\mathrm{Na}>\mathrm{Si}>\mathrm{Ti})$. Moreover, some other elements, such as sulphur or magnesium, were detected.

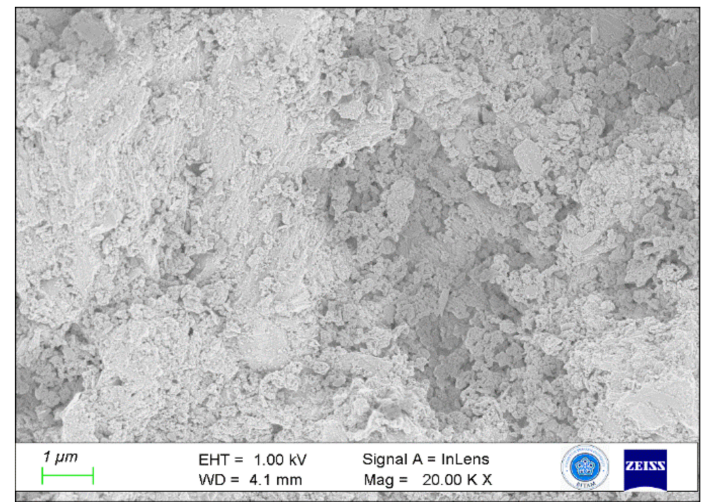

(a)

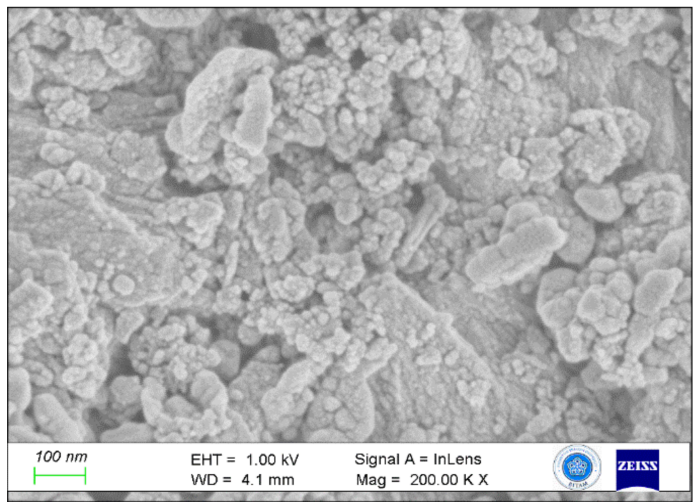

(b)

Figure 3. (a) FESEM Images of ALUM BR (20 Kx). (b) FESEM Images of ALUM BR (200 Kx). 

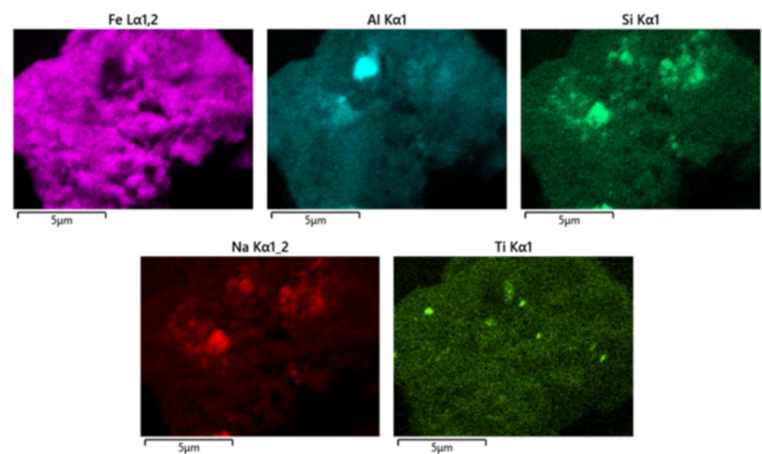

(a)

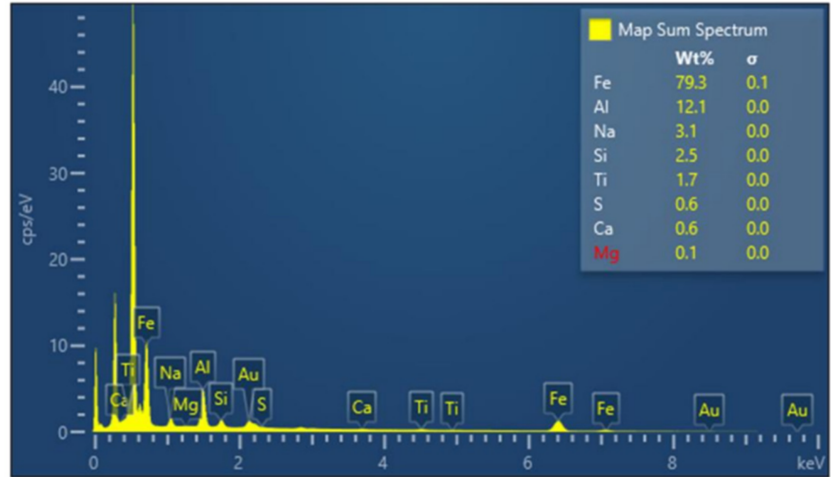

(b)

Figure 4. (a) X-ray mapping of the ALUM BR (10 kV, 20 Kx). (b) EDX Spectrum of ALUM BR.

Regarding AoG BR, SEM backscattered electron images and ESS spectrum are depicted in Figures 5-7. Figure 5 depicts a grain that mainly consists of Fe-oxide and/or oxyhydroxide, among them hematite, goethite, and magnetite, with hematite being the most possible according to the XRD and Rietveld analysis results presented. Figures 6 and 7 show grain with regions rich in calcite and Al-Si phase, and aluminium oxide, respectively. As can be seen, the particle size of the red mud sample generally ranges between $10 \mu \mathrm{m}$ and $100 \mu \mathrm{m}$.

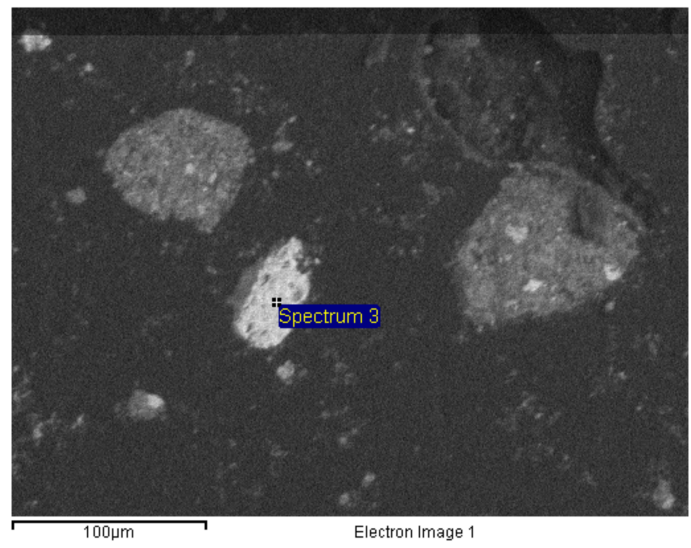

(a)

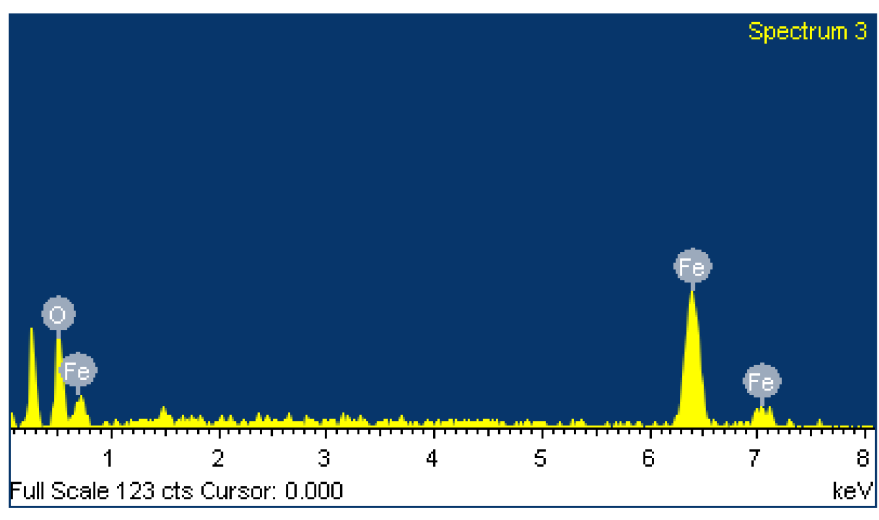

(b)

Figure 5. SEM of AoG sample-(a) image of hematite phase. (b) EDS of hematite phase.

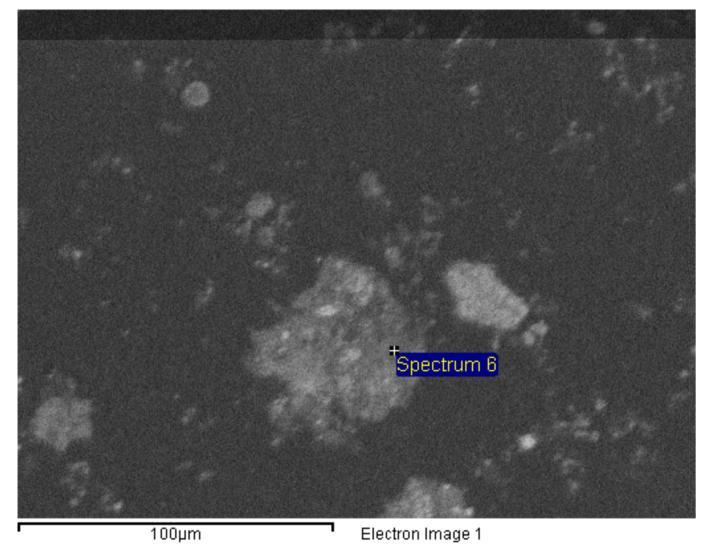

(a)

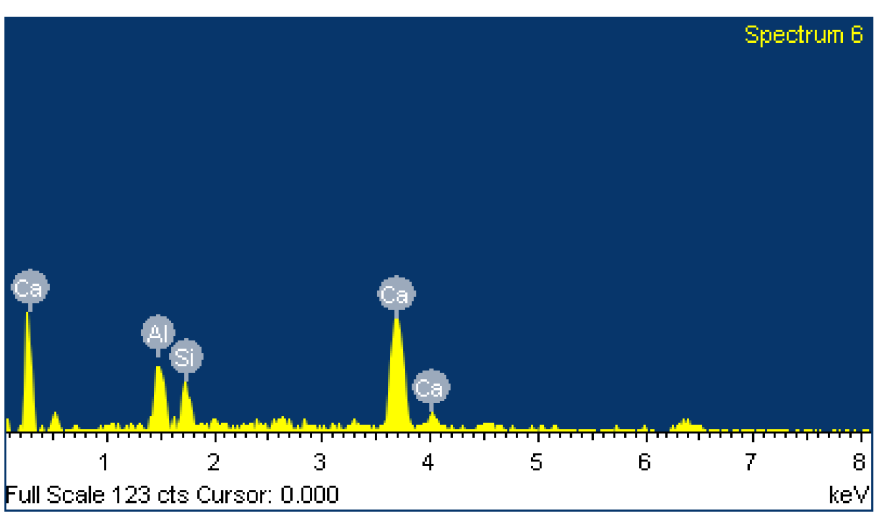

(b)

Figure 6. SEM of AoG sample-(a) image of a rich particle composed by calcite and Al-Si phase. (b) EDS of a rich particle composed of calcite and Al-Si phase. 


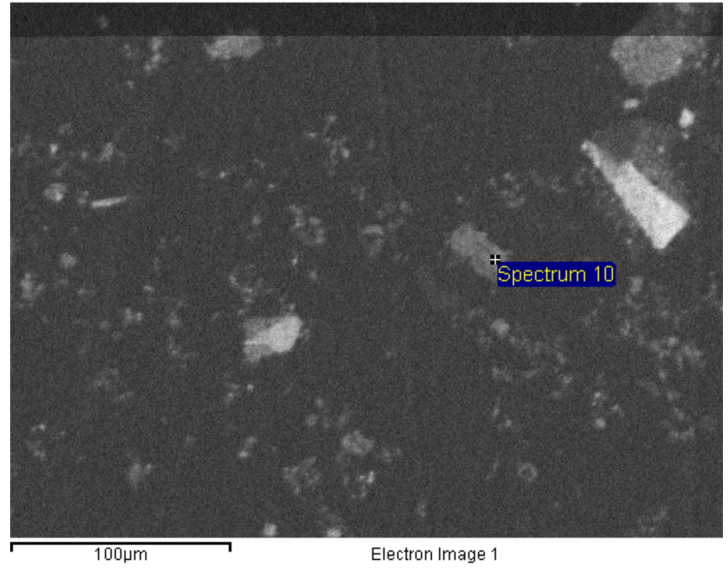

(a)

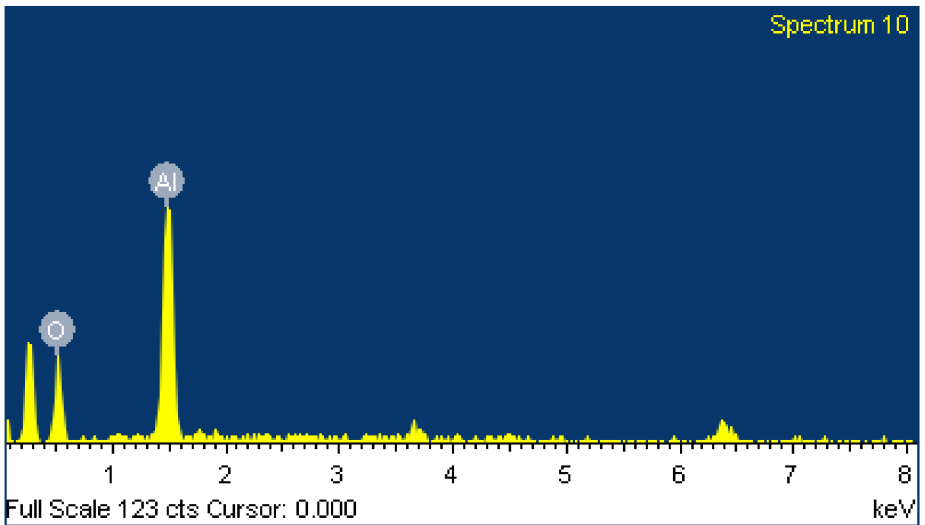

(b)

Figure 7. SEM of AoG sample-(a) image of aluminium oxide phase. (b) EDS of aluminium oxide phase.

SEM images of ETIBR are presented in Figure 8, and X-ray mapping in is presented in Figure 9. Sample consists of very fine particles with different shapes (rod, square, hexagonal). Considering only the major elements on the EDS mapping, the high colour intensities of some particles refer only to single metal oxides or hydroxides (Figure 9). On the other hand, signals from different elements are common to some particles, which are probably crystals containing two or more metallic elements (Ca-Ti, Al-Na-Si, etc.). The semi-quantitative analysis given with the EDS spectrum confirms the order of the major metal present within red mud $(\mathrm{Fe}>\mathrm{Al}>\mathrm{Si}>\mathrm{Na}>\mathrm{Ti}>\mathrm{Ca}$ ) (Figure 9). Moreover, some other elements, such as sulphur, magnesium or potassium, were detected.

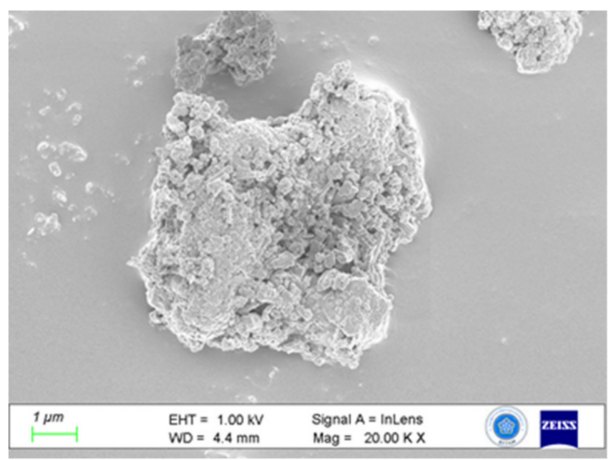

(a)

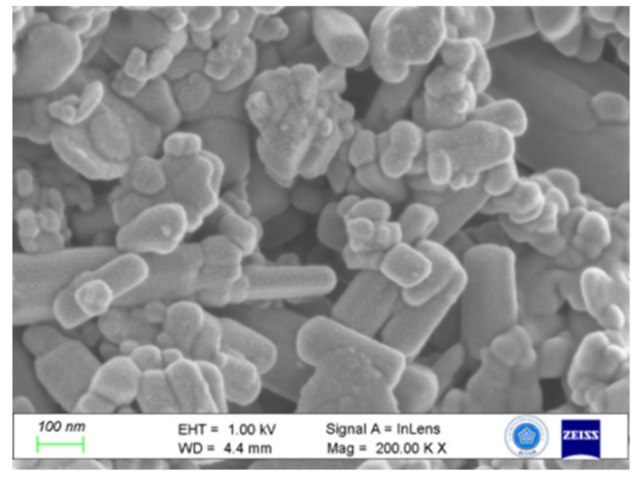

(b)

Figure 8. (a) SEM Image of BR ETI (20 Kx). (b) SEM Image of BR ETI (R200 Kx).
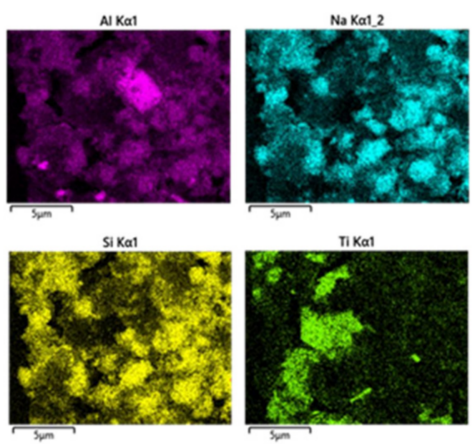

(a)
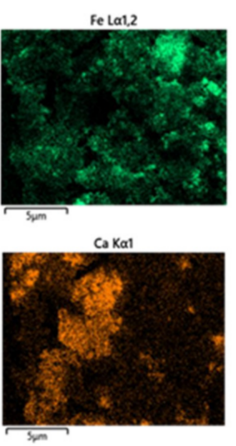

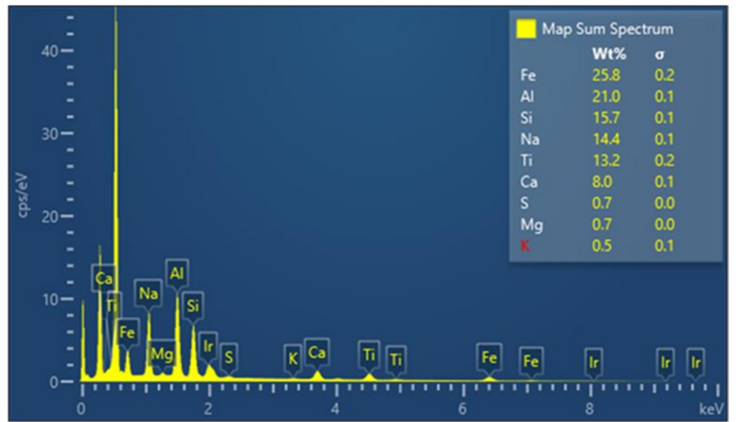

(b)

Figure 9. (a) X-ray mapping of ETI BR $(10 \mathrm{kV}, 15 \mathrm{Kx})$. (b) EDS spectrum of ETI BR. 


\section{Conclusions}

The conclusions drawn from the characterization of these bauxite residues are summarized as follows:

- Regarding partial chemical composition and preliminary solid phase characterization of BR samples, in general, small differences were observed, which can be attributed to the different origins of the ores used, as well as to the different processing conditions applied in the Bayer process. More significant deviations were identified for sodium and iron content. Major REEs and Sc scandium were detected in all cases. Their concentrations will be determined through ICP-MS on a following study.

- In the Romanian sample (ALUM), iron was mainly found in the form of goethite, while in the Greek (AoG) and the Turkish (ETI) samples, iron was structured in hematite.

- Despite the tiny size of BR particles, usually more than one phase coexist on a single grain, thus burdening the purity of samples that can be produced after the implementation of a physical separation procedure.

Funding: This research was implemented in the frame of REEScue project (ID: 82), which is funded by ERA-NET Cofund on Raw Materials (ERA min 2), under the Horizon 2020 Programme. This work was financially supported by the Scientific and Technological Research Council of Turkey (TUBITAK, No. 120N269). This work was supported by a grant of the Romanian National Authority for Scientific Research and Innovation-, CCCDI-UEFISCDI, project number ERANET-ERAMIN 3-REEScue, within PNCDI III.

Informed Consent Statement: Not applicable.

Conflicts of Interest: The authors declare no conflict of interest.

\section{References}

1. Power, G.; Gräfe, M.; Klauber, C. Bauxite residue issues: I. Current management, disposal and storage practices. Hydrometallurgy 2011, 108, 33-45. [CrossRef]

2. Milačič, R.; Zuliani, T.; Ščančar, J. Environmental impact of toxic elements in red mud studied by fractionation and speciation procedures. Sci. Total Environ. 2012, 426, 359-365. [CrossRef] [PubMed]

3. Hua, Y.; Heal, K.V.; Friesl-Hanl, W. The use of red mud as an immobiliser for metal/metalloid-contaminated soil: A review. J. Hazard. Mater. 2017, 325, 17-30. [CrossRef] [PubMed]

4. Vind, J.; Malfliet, A.; Blanpain, B.; Tsakiridis, P.; Tkaczyk, A.; Vassiliadou, V.; Panias, D. Rare earth element phases in bauxite residue. Minerals 2018, 8, 77. [CrossRef]

5. Vind, J.; Malfliet, A.; Bonomi, C.; Paiste, P.; Sajó, I.E.; Blanpain, B.; Tkaczyk, A.; Vassiliadou, V.; Panias, D. Modes of occurrences of scandium in Greek bauxite and bauxite residue. Miner. Eng. 2018, 123, 35-48. [CrossRef]

6. Ujaczki, E.; Zimmermann, Y.; Gasser, C.; Molnár, M.; Feigl, V.; Lenz, M. Red mud as secondary source for critical raw materialspurification of rare earth elements by liquid/liquid extraction. J. Chem. Technol. Biotechnol. 2017, 92, 2835-2844. [CrossRef]

7. Döbelin, N.; Kleeberg, R. Profex: A graphical user interface for the Rietveld refinement program BGMN. J. Appl. Crystallogr. 2015, 48, 1573-1580. [CrossRef] [PubMed] 